\title{
SUGARCANE MATURITY ESTIMATION THROUGH EDAPHIC-CLIMATIC PARAMETERS
}

\author{
Maximiliano Salles Scarpari ${ }^{1}$; Edgar Gomes Ferreira de Beauclair ${ }^{2 *}$ \\ ${ }^{1}$ USP/ESALQ - Programa de Pós-Graduação em Fitotecnia. \\ ${ }^{2}$ USP/ESALQ - Depto. de Produção Vegetal - C.P. 9 - 13418-900 - Piracicaba, SP - Brasil. \\ *Corresponding author <egfbeauc@esalq.usp.br>
}

\begin{abstract}
Sugarcane (Saccharum officinarum L.) grows under different weather conditions directly affecting crop maturation. Raw material quality predicting models are important tools in sugarcane crop management; the goal of these models is to provide productivity estimates during harvesting, increasing the efficiency of strategical and administrative decisions. The objective of this work was developing a model to predict Total Recoverable Sugars (TRS) during harvesting, using data related to production factors such as soil water storage and negative degree-days. The database of a sugar mill for the crop seasons 1999/2000, 2000/2001 and 2001/2002 was analyzed, and statistical models were tested to estimate raw material. The maturity model for a one-year old sugarcane proved to be significant, with a coefficient of determination $\left(\mathrm{R}^{2}\right)$ of 0.7049*. No differences were detected between measured and estimated data in the simulation $(P<0.05)$. Key words: sucrose, predicting, quality, mathematical model, climatology
\end{abstract}

\section{ESTIMATIVA DA MATURAÇÃO DA CANA-DE-AÇÚCAR POR MEIO DE PARÂMETROS EDAFOCLIMÁTICOS}

\begin{abstract}
RESUMO: A cultura da cana-de-açúcar (Saccharum officinarum L.) é submetida durante o seu desenvolvimento a diferentes condições ambientais que afetam diretamente a maturação. Modelos de previsão da qualidade da matéria-prima são ferramentas importantes no gerenciamento da lavoura canavieira, pois permitem estimativas de rendimento ao longo da safra, o que aumenta a eficácia das decisões gerenciais e estratégicas. O objetivo deste trabalho foi desenvolver um modelo capaz de obter estimativas de Açúcar Total Recuperável (ATR), utilizando dados referentes aos fatores de produção como armazenamento de água no solo e graus-dias negativos. Para o teste dos modelos estatísticos de estimativa da qualidade da matéria-prima foi utilizado o banco de dados de uma usina açucareira com produções das safras 1999/2000, 2000/2001 e 2001/ 2002. O modelo de maturação para cana de ano mostrou-se significativo, com um coeficiente de determinação $\mathrm{R}^{2}=0,7049 *$. Na simulação não houve diferença entre os dados medidos e estimados $(P<0,05)$.

Palavras-chave: sacarose, previsão, qualidade, modelo matemático, climatologia
\end{abstract}

\section{INTRODUCTION}

Sugarcane (Saccharum officinarum L.) crop is submitted to different environmental conditions, and maturation is directly affected by those conditions. Because of this variation along the cycle, predicting the crop's responses to those different stimuli may allow improved planning. Raw material quality predicting models are important tools in sugarcane cropping planning (Beauclair et al., 1993; Beauclair \& Scarpari, 2002), since they are aimed at characterizing management alternatives, creating more realistic scenarios for decision analysis simulations and optimizations, increasing the efficiency of management and strategic decisions along the cropping season (Boote et al., 1996; O’Leary, 2000).

Within this context, the planning of sugarcane harvest aims to optimize the crop's economic return (Beauclair \& Penteado, 1984; Crane et al., 1982), based on the concept that sugarcane presents, during the crop- ping season, a period known as optimal peak maturity for harvesting, at which the maximum concentration of sucrose occurs in the stalks. Inevitably, whether harvest planning is optimized or not, it uses agricultural yield and maturation estimates to determine the necessary resources and to fulfill execution timetables and carry out operations sequencing (Muchow et al., 1998; Salassi et al., 2002). The objective of this work was to develop models to estimate Total Recoverable Sugar (TRS) (CONSECANA, 1999), in kilograms of sucrose per ton of sugarcane, along the cropping season, using data related to the production factors soil water storage and negative degree-days.

Climate is the factor influencing sugarcane maturation the most (Alexander, 1973; Barbieri, 1993; Keating et al., 1999); maturation is governed by a complex of internal and external factors (Van Dillewijn, 1952). Climatic elements such as precipitation and air temperature vary according to the conditions in different producing areas, 
and the models that do not address this effect in particular can, at most, represent a fraction of the total variation in maturity and are restricted to the same climate condition (Beauclair, 1994). Scarpari (2002) used monthly precipitation data to build a maturity predicting model but this is not, however, the best method to verify the influence of water availability on maturity. The best method to achieve those results is the water balance method (Thornthwaite \& Mather, 1955), in which precipitation and evapotranspiration are taken into account, in addition to the soil's Available Water Capacity (AWC) (Doorenbos \& Kassam, 1979), where the result is soil water storage (Barbieri et al., 1997; Inman-Bamber \& Kiker, 1997). Several authors have modeled the influence of evapotranspiration on crop productivity (Barbieri, 1981; Ometto, 1978; Thompson, 1976). However, the influence of water availability on maturity has not yet been sufficiently studied. Humbert (1968) observed that for the process of physiological maturity to occur where a seasonal reduction of air temperature does not occur, the crop must be submitted to a moderate drought, inducing sucrose accumulation in the plant's tissues.

Another factor influencing maturity herein considered is cold. According to Alexander (1973), the process of physiological maturity depends on the seasonal reduction of air temperature, slowing down the rate of vegetative development without, however, significantly affecting the process of photosynthesis, so that a greater amount of photosynthesized products transformed into sugars will be available for storage within the plant's tissues.

The partitioning of photosynthates was modeled by Liu \& Bull (2001). The authors considered the mean air temperature a factor of influence on the distribution of those photosynthates, demonstrating the importance of the seasonal reduction of the air temperature on maturity and sucrose partitioning. Under low night temperatures, development is slow and an increase in the concentration of sucrose in the plant's stalks is observed.

\section{MATERIAL AND METHODS}

This project was developed from sugarcane harvest results obtained in Pontal, State of São Paulo, Brazil ( $\left.21^{\circ} 00^{\prime} \mathrm{S}, 48^{\circ} 02^{\prime} 23^{\prime \prime} \mathrm{W}\right)$, mean temperature of $22.4^{\circ} \mathrm{C}$, mean annual precipitation of $1,598 \mathrm{~mm}$, and mean altitude of $515 \mathrm{~m}$. Water balance for the evaluated period is presented in Figures 1, 2, and 3.

Data from 74 sugarcane stands in the 1999/2000, 2000/2001 and 2001/2002 cropping seasons were analyzed in terms of quality (TRS), stand age, climatic parameters, soil, and management. Statistical models for raw material quality estimation were tested using the SAS "Statistical Analysis System" software (SAS Institute, 1989).

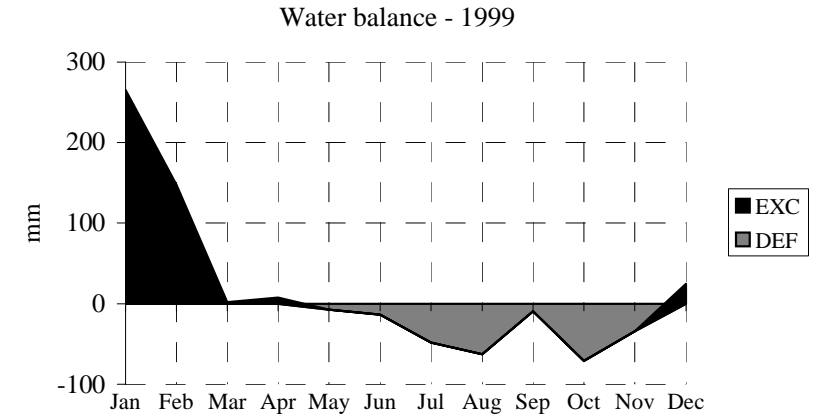

Figure 1 - Monthly water balance (Rolim \& Sentelhas, 1997) for the Pontal/SP region in the year 1999.

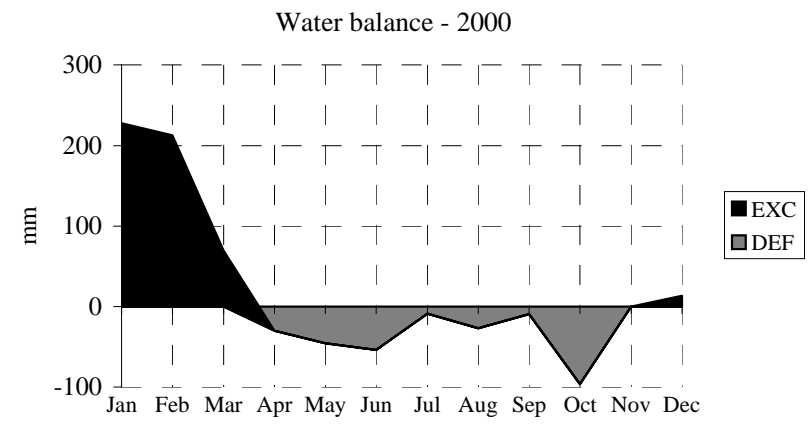

Figure 2 - Monthly water balance (Rolim \& Sentelhas, 1997) for the Pontal/SP region in the year 2000.

Water balance - 2001

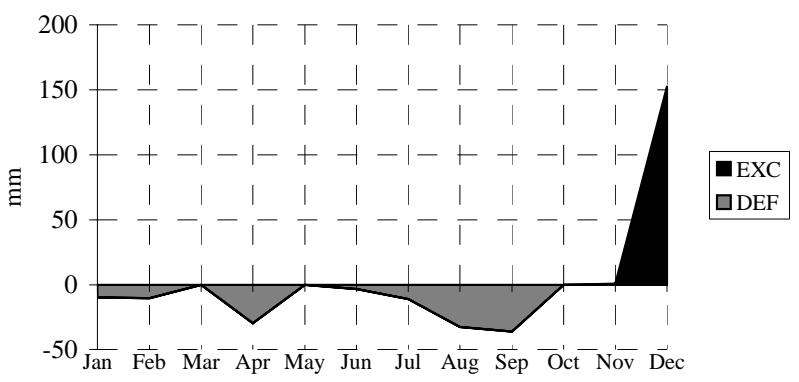

Figure 3 - Monthly water balance (Rolim \& Sentelhas, 1997) for the Pontal/SP region in the year 2001.

The method utilized to correlate maturity and temperature was the negative degree-days method, which corresponds to the area comprised between the base temperature, below which development is considered null, and the daily minimum temperature (Scarpari, 2002). Barbieri et al. (1979) determined the base temperature for sugarcane to be around $20^{\circ} \mathrm{C}$. Figure 4 demonstrates how this factor was calculated.

For $\mathrm{Tb}>\mathrm{Tm}$

Negative degree-days $=(\mathrm{Tb}-\mathrm{Tm})^{2} \times$ no. days in the month; $\quad 2$ (TM - Tm)

For $\mathrm{Tb} \leq \mathrm{Tm}$, Negative degree-days $=0$;

where: $\mathrm{TM}=$ mean monthly maximum temperature $\left({ }^{\circ} \mathrm{C}\right)$, $\mathrm{Tm}=$ mean monthly minimum temperature $\left({ }^{\circ} \mathrm{C}\right), \mathrm{Tb}=$ base temperature $\left({ }^{\circ} \mathrm{C}\right)=20^{\circ} \mathrm{C}$ (Barbieri et al., 1979). 


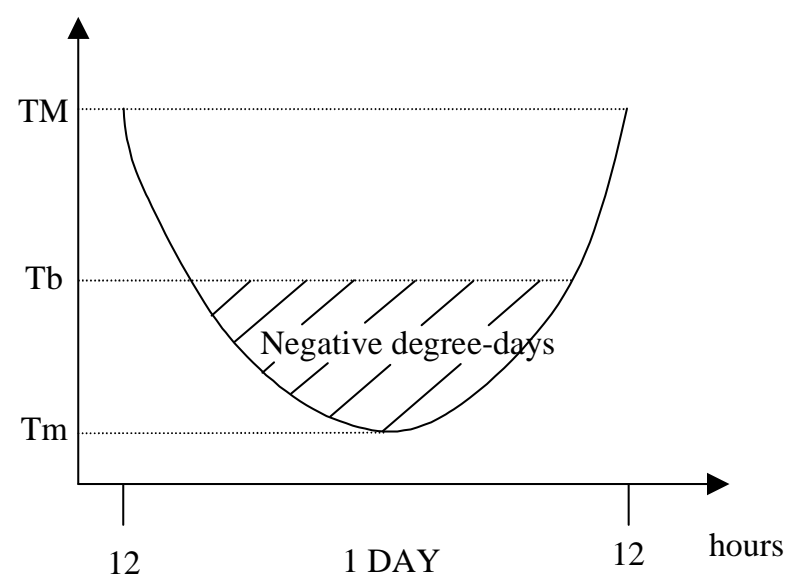

Figure 4 - Negative degree-days $\left({ }^{\circ} \mathrm{C}\right)$.

With regard to the soil, a mean Available Water Capacity (AWC) of $100 \mathrm{~mm}$ was considered for the Rhodic Eutrudoxes, with moderated A horizon, very clayey-textured soils (Embrapa, 1999) found at the sugar mill plant, and monthly storage was used as an independent variable in the model.

The agroclimatic model used in this work is defined by a mathematical expression that relates the dependent variable TRS $(\mathrm{Y})$ to the independent variables defined as soil water storage and negative degree-days in the five months preceding harvest at each stand, in the following way:

$\mathrm{Y}=\mathrm{a}+\mathrm{b}_{1} \operatorname{arm} 1+\mathrm{b}_{2} \mathrm{arm} 2+\mathrm{b}_{3} \mathrm{arm} 3+\ldots+\mathrm{b}_{10}$ frio5;

where: $\mathrm{Y}=$ dependent variable for the model (TRS), arm1 $=$ storage in the month preceding harvest in the stand $(\mathrm{mm})$, arm2 = storage in the second month preceding harvest in the stand $(\mathrm{mm})$, arm3 = storage in the third month preceding harvest in the stand $(\mathrm{mm}), \operatorname{arm} 4=$ storage in the fourth month preceding harvest in the stand (mm), $\operatorname{arm} 5=$ storage in the fifth month preceding harvest in the stand $(\mathrm{mm})$, frio1 $=$ negative degree-days in the month preceding harvest in the stand $\left({ }^{\circ} \mathrm{C}\right)$, frio2 $=$ negative degree-days in the second month preceding harvest in the stand $\left({ }^{\circ} \mathrm{C}\right)$, frio $3=$ negative degree-days in the third month preceding harvest in the stand $\left({ }^{\circ} \mathrm{C}\right)$, frio $4=$ negative degree-days in the fourth month preceding harvest in the stand $\left({ }^{\circ} \mathrm{C}\right)$, frio5 $=$ negative degree-days in the fifth month preceding harvest in the stand $\left({ }^{\circ} \mathrm{C}\right)$.

Determination of parameters $b_{1}, b_{2}, b_{3}, \ldots, b_{9}$ and $\mathrm{b}_{10}$ in the adopted equation was performed using the "REG" procedure and the "STEPWISE" method, where the independent variables that take part in the model are selected through multiple linear regression. The "STEPWISE" method is used when the hypothesis is to predict or relate a sample to one or more independent variables (Robbins \& Danemam, 1999). Therefore, the relation between dependent and independent variables is explained, determining a logical relationship between them. In all procedures, the analysis of variance for the multiple linear regression was tested by the $\mathrm{F}$ test (Spiegel, 1972), up to the 10\% probability error level for rejecting the null hypothesis. This level is ordinarily used in works dealing with random variables (Hoffman \& Vieira, 1977).

The parameter known as coefficient of determination $\left(\mathrm{R}^{2}\right)$ was used as indicator of the model's precision.

$\mathrm{R}^{2}=\mathrm{SSR} / \mathrm{SST}$

where: $\mathrm{R}^{2}=$ coefficient of determination, SSR = regression sum of squares, $\mathrm{SST}=$ total sum of squares.

The Chi-square adherence test was used in the model simulation and in the comparison between TRS measured in the stands and TRS estimated by the model; the measured frequencies were adjusted to proportions established by convenient theories or hypotheses (Gomes, 1990). The statistical level of significance was set at $5 \%$. Calculation was performed using the formula:

$\chi^{2}=\frac{\sum(\mathrm{fm}-\mathrm{fe})^{2}}{\mathrm{fe}} ;$

where: $\chi^{2}=$ Chi-square, $\mathrm{fm}=$ frequencies measured at the stands, $\mathrm{fe}=$ frequencies estimated by the model.

\section{RESULTS AND DISCUSSION}

The maturity estimation model, constructed based on the 1999/2000 and 2000/2001 cropping seasons for one-year old sugarcane, was significant, and is presented below:

TRS = $132.01194+0.45527$ arm $4+0.30505$ frio5 0.27412 frio3; $\quad \mathrm{R}^{2}=0.7049 *$

where: TRS = Total Recoverable Sugar (in kg sugar per ton of sugarcane), arm $4=$ storage in the fourth month preceding harvest in the stand (in $\mathrm{mm}$ ), frio5 = negative degree-days in the fifth month preceding harvest in the stand (in ${ }^{\circ} \mathrm{C}$ ), frio3 = negative degree-days in the third month preceding harvest in the stand (in ${ }^{\circ} \mathrm{C}$ ).

The concept of negative degree-days adopted in this work was extremely valuable for selecting independent variables for the model, such as the positive signal of the parameter estimated for variable frio5, indicating a beneficial effect of cold on sucrose accumulation. This effect was explained by Alexander (1973), who reported that night temperatures below $20^{\circ} \mathrm{C}$ affect plant's metabolism, limiting nutrients and water movement toward the leaves and causing a decrease in the contents of those elements, thus affecting growth. Since growth represents the opposite of sucrose storage, the activity of the invertase enzyme is increased (Taiz \& Zeiger, 1998), with 
transport of sucrose from the cytosol into the vacuoles at the expense of energy. This transport occurs at a higher degree at night, when the stomata are closed and no transpiration occurs. Therefore, plants supplied with good levels of water, temperature (i.e., high), and nutrients, do not enter the maturation process. One single stimulus contrary to those listed above is sufficient to trigger the process. Humbert (1968) also observed effect of low temperatures on growth metabolism reduction and maturity induction, even when the levels of nitrogen and soil moisture are adequate. When maturity is induced by nitrogen deficiency, an increase in the content of reducing sugars, and a decline in the percentage of recoverable sugar occurs, which is undesirable, indicating that the best factor for naturally triggering maturity is cold indeed; an adequate content of nitrogen in the plant is also necessary.

As previously stated, there is a relationship between the enzyme invertase and the rate of sucrose storage into the vacuoles of mature tissues (Hatch \& Glasziou, 1963), indicating that sucrose storage increases or decreases depending on the activity of the enzyme invertase in the cytosol. Several research reports on the mechanism of action of invertase and other enzymes that act on this process have been published, one of the most recent being Rohwer \& Botha (2001). However, not all steps of the reactions involved have been described in detail, and more conclusive studies are required. Hormones, such as gibberellins and abscisic acid (ABA), in addition to their action on flowering, germination, and stomata closing, also participate in maturation, and their reactions are influenced by cold (Salisbury \& Ross, 1991).

The positive signal of the parameter estimated for variable arm4, although apparently contradicting the literature, is not altogether surprising, since a severe drought prior to harvesting, which occurred in the months of May, June, July, and August in the years 1999 and 2000 is not beneficial, since the stomata close to save water, causing a decrease in transpiration, gaseous exchanges, $\mathrm{CO}_{2}$ assimilation, and sucrose accumulation. As seen in Humbert (1968), water stress affects sugarcane quality as sucrose is inverted into glucose and fructose. Therefore, a marked water deficiency for the plant near the beginning of the maturation stage could negatively affect the production of sucrose.

The independent variable frio3, selected by the "STEPWISE" method, indicated a deppressive effect of cold in the third month preceding harvest in the stand on sucrose accumulation. This result does not contradict the literature, and could be an indication that the selection of variable frio3 was due to a mathematical adjustment inherent to the method of analysis in search for higherweight variables in the final coefficient of determination $\left(\mathrm{R}^{2}\right)$, a particularity commented by Robbins \& Danemam
(1999). On the other hand, it could be hypothesized that excessive cold, around $9^{\circ} \mathrm{C}$, which occurred in the third month preceding harvest in each year, would consume chemical energy or the plant to recover its physiological metabolism, in addition to affecting the process of photosynthesis and phloem sap viscosity, interfering with sucrose transport and storage from the leaves into the stalks. Du et al. (1999) measured the photosynthesis rate and metabolism of the crop when exposed to a temperature of $10^{\circ} \mathrm{C}$ for periods of 4,28 , and 52 hours, and observed a decrease in photosynthesis rate by more than $50 \%$ and a reduction in the activity of enzymes PPDK and NADPMDH by 70\%; these are enzymes that can determine cold sensitivity on the photosynthesis rate and on sucrose synthesis.

Varieties from tropical regions have been observed to be more sensitive to cold when compared with varieties from temperate regions. Thus, there is a limit for the benefits resulting from low temperatures on the maturity and quality of sugarcane as a raw material for industrialization. Possibly, a higher number of observations (cropping seasons) will allow better adjustments and explanations for this selected variable, in addition to evaluations and analyses of the metabolism involved in maturation. The $\mathrm{R}^{2}$ value of $0.7049 *$ is significant, indicating that the model explains about $70 \%$ of TRS variation as a function of the variations of the selected variables, with the remaining $30 \%$ being caused by factors not considered in the model, such as the varietal difference detected through several maturity curve standards. Varieties such as RB855536 and SP80-1842 (Copersucar, 1993), planted in the same season and harvested during the months of August through October show distinct maturity curves, a genetic character inherent to each variety. Resistance to lodging is another trait specific to each variety; this is an undesirable phenomenon, because when it occurs it is accompanied by lateral bud sprouting and sucrose consumption.

Local particularities, such as low-lying areas, tend to accumulate more water in the soil, delaying maturity. Attack by pests and diseases could invert sucrose, while specific differences in management and age also influence maturity. These factors can and must be isolated in future works, by selecting the data according to certain criteria, for instance, records of a given variety or a certain planting season or cut. However, because of the nature of the analysis, a greater number of data will be needed. These procedures will increase the precision of estimates.

Since the null hypothesis was rejected by the model ( $F$ value is statistically significant), the effect of the selected variables must be taken into account in all simulations; it must be kept in mind that the deppressive effect of variable frio3 is still subject to hypotheses, or, 
in other words, it could be inherent to the mathematical adjustment of the method that was used or to an effect linked to the intensity of that factor, as reported by Du et al. (1999). Therefore, the model could supply an estimate for the TRS values, up to three months in advance before harvesting the one year-old sugarcane varieties planted at that place, thus allowing a better evaluation of the production scenario.

After building the model, validation simulations were performed, in which the estimated productivities generated by the model for the cropping season corresponding to the one year-old sugarcane harvesting was compared to the productivities actually measured for the 2001/2002 cropping season. Results are presented in figure 5 .

By applying the Chi-square test to the measured and estimated data from Figure 5, a $\chi^{2}$ value of 24.03 is obtained. By looking up the value in the $\chi^{2}$ table (Hoffman, 1980) for $P<0.05$ and d.f. $=73$, a $\chi^{2}$ value of $\cong 95$ was found. Since the calculated Chi-square value is smaller than the table value, there is no significant statistical difference at 5\%, with acceptance of both Ho and the hypothesis of equal frequencies. Thus, the $\chi^{2}$ test result presented in Figure 5 indicates that the proposed model is suitable for estimating maturity in one year-old sugarcane, with an $\mathrm{R}^{2}=0.8646$ when fitting the data estimated by the model, and an $\mathrm{R}^{2}=0.2704$ when fitting the data measured in the stands. An excellent fitting of the estimated data can be observed; however, the measured data showed great variation and poor fitting to the quadratic model, especially because of the decrease in TRS in the month of December. This deviation has small relative importance, since harvesting hardly extends beyond the 15th of that month. As previously mentioned, a greater number of observations (cropping seasons) and the repetition of these procedures will provide better simulation fitting, but these results already allow the use of this model to estimate the future quality of the raw

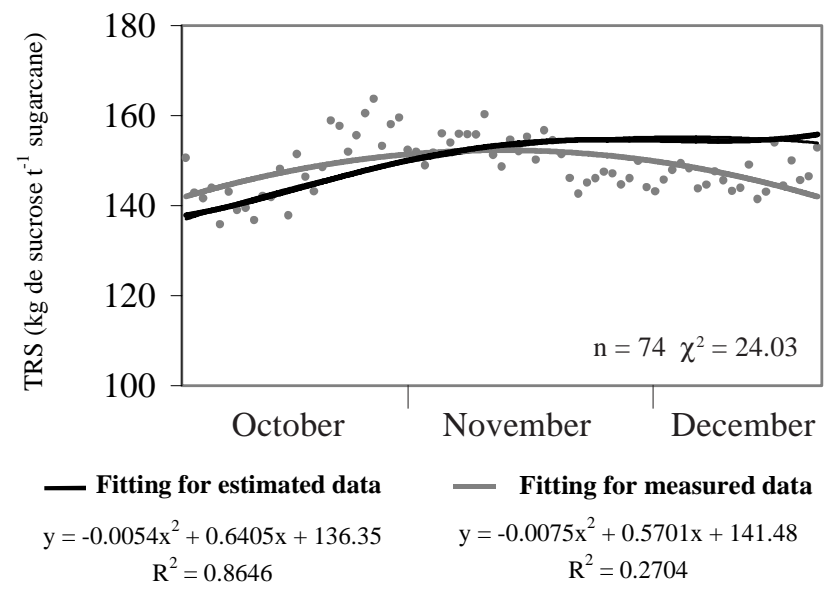

Figure 5 - Simulation between TRS measured in the stands and estimated by the model, for one year-old sugarcane. material, especially when creating more realistic scenarios, which will provide data for planning studies and decision analyses.

With regard to agronomic implications, TRS predictions are made currently for agronomical planning by using maturity curves obtained in assays of varieties cleared by research organizations or by consulting the history for the area, with great prediction errors, resulting from the huge knowledge gap with respect to the quantitative effects that the factors exert over yields. When it comes to sugar export contracts and harvest planning (whether optimized or not), these estimates based solely on history become extremely fragile. In the presented model, however, an error smaller than $5 \%$ represents a great improvement, demonstrating that this tool is viable for agroindustrial and agronomic strategics and planning.

\section{REFERENCES}

ALEXANDER, A.G. Sugarcane physiology: a comprehensive study of the Saccharum source-to-sink system. Amsterdam: Elsevier, 1973. 752p.

BARBIERI, V. Medidas e estimativas de consumo hídrico em cana-de-açúcar (Saccharum spp.). Piracicaba: USP/ESALQ, 1981. 82p. (Dissertação Mestrado).

BARBIERI, V. Condicionamento climático da produtividade potencial da cana-de-açúcar (Saccharum spp.): Um modelo matemático-fisiológico de estimativa. Piracicaba: USP/ESALQ, 1993. 140p. (Tese - Doutorado).

BARBIERI, V.; BACCHI, O.O.S.; VILLA NOVA, N.A. Análise do fator temperatura média do ar no desenvolvimento da cana-de-açúcar (Saccharum spp.) In: CONGRESSO BRASILEIRO DE AGrometeorologiA, 1., Mossoró, 1979. Anais. Mossoró, 1979. p.192-197.

BARBIERI, V.; TERUEL, D.A.; SILVA, J.G. da; SANTOS, R.M.N. dos. Balanço hídrico de Thornthwaite e Mather modificado para estimativa de deficiências nas culturas. In: CONGRESSO BRASILEIRO DE AGrometeorologiA, 10., Piracicaba, 1997. Anais. Piracicaba, 1997. p.587-589.

BEAUCLAIR, E.G.F. de. Produtividade da cana-de-açúcar em função de alguns macronutrientes presentes no caldo e no solo. Piracicaba: USP/ ESALQ, 1994. 98p. (Tese - Doutorado).

BEAUCLAIR, E.G.F. de; PENTEADO, C.R. Cronograma de corte da canade-açúcar através da programação linear. In: SEMINÁRIO DA TECNOLOGIA AGRONÔMICA, 2., Piracicaba, 1984. Anais. Piracicaba: Centro de Tecnologia Copersucar, 1984. p.424-434.

BEAUCLAIR, E.G.F. de; SCARPARI, M.S. Modelo de previsão de acúmulo de sacarose para a cana-de-açúcar (Saccharum spp.) através de parâmetros climáticos. In: CONGRESSO NACIONAL DOS TÉCNICOS AÇUCAREIROS E ALCOOLEIROS DO BRASIL, 8., Recife, 2002. Anais. Recife: STAB, 2002. p.561-565.

BEAUCLAIR, E.G.F. de; COSTA, R.P. da; BITTENCOURT, V.C. de; GIRARDI, G. Informática na lavoura canavieira. In: CONGRESSO NACIONAL STAB, 5., Águas de São Pedro, 1993. Anais. Piracicaba: STAB, 1993. p.294-297.

BOOTE, K.J.; JONES, J.W.; PICKERING, N.B. Potential uses and limitations of crop models. Agronomy Journal, v.88, p.704-716, 1996. CONSELHO DOS PRODUTORES DE CANA-DE-AÇÚCAR, AÇÚCAR E ÁLCOOL DO ESTADO DE SÃO PAULO. Manual de instruções. Piracicaba: CONSECANA, 1999. 92p.

COOPERATIVA CENTRAL DOS PRODUTORES DE AÇÚCAR E ÁLCOOL DO ESTADO DE SÃO PAULO. Quarta geração de variedades de cana-de-açúcar Copersucar. Piracicaba: COPERSUCAR, 1993. p.12-16.

CRANE, D.R.; SPREEN, T.H.; ALVAREZ, J.; KIDDER, G. An analysis of the stubble replacement decision for Florida sugarcane growers. Gainesville: University of Florida, 1982. 74p. 
DOORENBOS, J.; KASSAM, A. H. Efectos del agua sobre el rendimiento de los cultivos. Roma: FAO, 1979. 212p. (Riego y Drenaje, 33).

DU, Y.-C.; NOSE, A.; WASANO, K. Effects of chilling temperature on photosynthetic rates, photosynthetic enzyme activities and metabolism levels in leaves of three sugarcane species. Plant, Cell and Environment, v.22, p.317-324, 1999.

EMPRESA BRASILEIRA DE PESQUISA AGROPECUÁRIA. Sistema brasileiro de classificação de solos. Rio de Janeiro: Embrapa Solos, 1999. 412p.

GOMES, F.P. Curso de estatística experimental. Piracicaba: Nobel, 1990. 469p.

HATCH, M.D.; GLASZIOU, K.T. Sugar accumulation cycle in sugarcane. II. Relationship of invertase activity to sugar content on growth tissue of plants grown in controlled environments. Plant Physiology, v.38, p.344-348, 1963.

HOFFMAN, R. Estatística para economistas. São Paulo: Pioneira, 1980. 379p.

HOFFMAN, R.; VIEIRA, S. Análise de regressão: uma introdução a econometria. 2.ed. São Paulo: Hucitec, 1977. 379p.

HUMBERT, R.P. The growing of sugarcane. Amsterdam: Elsevier, 1968. 779p.

INMAN-BAMBER, N.G.; KIKER, G. CANEGRO 3.10: DSSAT version 3.1 distribution software. Honolulu: IBSNAT, University of Hawaii, 1997.

KEATING, B.A.; ROBERTSON, M.J.; MUCHOW, R.C.; HUTH, N.I. Modelling sugarcane production systems I. Development and performance of the sugarcane module. Field Crops Research, v.61, p.253-271, 1999.

LIU, D.L.; BULL, T.A. Simulation of biomass and sugar accumulation in sugarcane using a process-based model. Ecological Modelling, v.144, p.181-211, 2001.

MUCHOW, R.C.; HIGGINS, A.J.; RUDD, A.V.; FORD, A.W. Optimizing harvest date in sugar production: a case study for the Mossman mill region in Australia II. Sensitivity to crop age and crop class distribution. Field Crops Research, v.57, p.243-251, 1998.

O'LEARY, G.J. A review of three sugarcane simulation models with respect to their prediction of sucrose yield. Field Crops Research, v.68, p.97111,2000
OMETTO, J.C. An equation for the estimation of agro-industrial sugarcane yield in the Piracicaba region. In: INTERNATIONAL SOCIETY SUGARCANE TECHNOLOGISTS, 16., São Paulo, 1978. Proceedings. São Paulo: ISSCT, 1978. p.899-905.

ROBBINS, J.L.; DANEMAN, J.C. Parametric estimating \& the stepwise statistical technique. National Estimator, v.14, p.24-34, 1999.

ROHWER, J.M.; BOTHA, F.C. Analysis of sucrose accumulation in the sugarcane culm on the basis of in vitro kinetic data. Biochemical Journal, v.358, p.437-445, 2001.

ROLIM, G.S.; SENTELHAS, P.C. BHnorm v2.0: Balanço hídrico normal por Thornthwaite \& Mather (1955). Piracicaba: ESALQ/USP, 1997.

SALASSI, M.E.; BREAUX, J.B.; NAQUIN, C.J. Modeling within-season sugarcane growth for optimal harvest system selection. Agricultural Systems, v.73, p.261-278, 2002.

SALISBURY, F.B.; ROSS, C.W. Plant physiology. California: Wadsworth, 1991. 682p.

SAS INSTITUTE. SAS Language and procedures: Usage, Version 6. Cary, NC: Sas Institute, 1989. 638p.

SCARPARI, M.S. Modelos para a previsão da produtividade da cana-deaçúcar (Saccharum spp.) através de parâmetros climáticos. Piracicaba: USP/ESALQ, 2002. 79p. (Dissertação - Mestrado).

SPIEGEL, M.R. Estatística. São Paulo: McGraw-Hill do Brasil, 1972. 580p.

TAIZ, L.; ZEIGER, E. Plant physiology. California: The Benjamin/ Cummings Publishing Co., 1998. 559p.

THOMPSON, G.D. Water use by sugarcane. South African Sugar Journal, v.1, p.593-600, p.627-635, 1976.

THORNTHWAITE, C.W.; MATHER, J.R The water balance. New Jersey: Centertown, 1955. 104p.

VAN DILLEWIJN, C. Botany of sugarcane. Waltham: The Chronica Botanica, 1952. 371p.

Received October 11, 2002

Accepted June 24, 2004 